\title{
Aquaculture as a Component for Livelihood Development of Tribal Farmers of Selected Blocks of Koraput District, Odisha, India
}

B. C. Mohapatra ${ }^{*}$, Prabhati K. Sahoo ${ }^{1}$, K. D. Mahapatra ${ }^{1}$, A. Barat ${ }^{1}$, P. K. Sahoo ${ }^{1}$, G. M. Siddaiah ${ }^{1}$, D. Panda ${ }^{1}$, U. L. Mohanty ${ }^{1}$, D. K. Verma ${ }^{1}$, D. Majhi ${ }^{1}$, J. K. Swain ${ }^{1}$, P. Adhikari ${ }^{2}$, L. Panda ${ }^{2}$, B. Ratha ${ }^{3}$ and B. R. Pillai ${ }^{1}$

${ }^{1}$ ICAR-Central Institute of Freshwater Aquaculture, Bhubaneswar - 751002, Odisha, India ${ }^{2}$ PRAGATI, Pujariput, Koraput, Odisha, India

${ }^{3}$ District Fisheries Office, Jeypore, Koraput District, Odisha, India

*Corresponding author

\section{A B S T R A C T}

\section{Keywords}

Fish production, ponds, Koraput

District,

Technology demonstration, Tribal farmers,

Livelihood

development

\section{Article Info}

Accepted:

04 August 2020

Available Online:

10 September 2020
Freshwater aquaculture as a component in livelihood development and nutritional security of 221 tribal farmers was undertaken in 58 villages under 17 Gram Panchayats of Koraput, Kotpad, Borigumma, Nandapur and Jeypore Blocks of Koraput District, Odisha during 2018-19. One hundred seventy six ponds with total water area of 22.168 ha were adopted by ICAR-Central Institute of Freshwater Aquaculture, Bhubaneswar for technology demonstration. Fingerlings of Indian Major Carps (IMC) i.e., Catla catla (Catla), Labeo rohita (Rohu) and Cirrihinus mrigala (Mrigal) with species ratio 1:2:1, and size range 42$85 \mathrm{~mm}$ length and 3-7 g weight were stocked in October-November, 2018 in the ponds at a lower density of 3,500 nos/ha. With minimal technical interventions like, liming of pond, seed stocking, training, etc. the fish production achieved was $777.4-1445 \mathrm{~kg} / \mathrm{ha} / \mathrm{yr}$ (average $1206.6 \mathrm{~kg} / \mathrm{ha} / \mathrm{yr}$ ) from a negligible level of production of less than $200 \mathrm{~kg} / \mathrm{ha} / \mathrm{yr}$ before adoption. The fish survival was $35-60 \%$. During the culture period, around $20-30 \%$ of total fish produced had gone to the nutritional security of the adopted families. The rest was sold and the revenue was taken to the common fund of the tribal groups. Prior to adoption, per capita fish availability from ponds for consumption of the tribal population of that area was less than $0.01 \mathrm{~kg} / \mathrm{day}$, which rose to $0.025 \mathrm{~kg} /$ day after adoption. The present investigation of ICAR-CIFA not only brought a ray of hope to the remotely residing tribal communities, who never thought of aquaculture as a livelihood option but also equipped them to utilise the available water resources through aquaculture with marginal improvement in their livelihood and nutritional security.

\section{Introduction}

Aquaculture as a sunshine sector is providing food, nutritional security and livelihood to more than 14 million people around the world
(FAO, 2010). It is a very important economic activity and also emerging sector with varied resources and potentials in many states of India. The vibrancy of the sector is seen in India by sixteen fold increase in fish 
production in last six decades i.e., from 0.75 MMT in 1950-51 to 13.75 MMT in 2018-19. In last few decades, aquaculture became the fast growing food producing sector; however it still stands inadequate to meet the nutritional demand in the country, particularly in tribal areas. Almost all small-scale fish farmers of the world (98\%) are in developing countries - mostly in rural areas (Shrestha and Pant, 2012; Rajee and Mun, 2017) and aquaculture component for rural development has had a poor record in many developing countries (Mondal et al., 2012).

The state of Odisha is situated in the eastern part of India, with $4.7 \%$ of country's landmass and $3.74 \%$ population. Total population of Odisha is 41.9 million in 2011, among which Scheduled Caste and Scheduled Tribe population constitute $17.1 \%$ and $22.8 \%$ respectively and together constitute $39.9 \%$ of the total state population (www.censusindia.gov.in). This is slightly higher than the all India figures of $16.6 \% \mathrm{SC}$ and $8.6 \%$ ST population. Around $41.8 \%$ of the total state population depends on daily wages (Census, 2011) out of which the percentage of main workers and marginal workers are $61.0 \%$ and $18.3 \%$ respectively. Koraput District, Odisha lies at 17.4-20.7 ${ }^{\circ} \mathrm{N}$ Latitude and 81.24-84.2 ${ }^{\circ} \mathrm{E}$ Longitude. It covers an area of $8807 \mathrm{sq} \mathrm{km}$ and experiences minimum $12.0^{\circ} \mathrm{C}$ and maximum $38.0^{\circ} \mathrm{C}$ temperature (https://koraput.nic.in/aboutdistrict/). The district has total population of $1,379,647$ as per the Census 2011 (https://www.censusindia.co.in/district/korapu t-district-odisha-398). Schedule Caste (SC) population constitutes $14.2 \%$ while Schedule Tribe (ST) $50.6 \%$ of total population. Out of total population, $16.4 \%$ people lives in urban areas, while $83.6 \%$ lives in the rural areas.

Aquaculture can be a profitable culture practice for farmers of Odisha as $80 \%$ of total population consumes fish as a source of animal protein. Hence, the expansion of aquaculture can provide livelihood option, food security and better economic returns to the farming communities of the state. Odisha has 6.83 lakh ha of freshwater resources and total fish production of the state during 201718 was 6.08 lakh tonnes (GoO, 2017-18). It has reached to 7.0 lakh tonnes by 2018-19. Despite having rich resources for aquaculture, 36,965 tonnes of fish were imported from neighbouring state of Andhra Pradesh to meet growing demand for fishes in Odisha (The Pioneer, 2017). For augmenting fish production, the basic premises of rural development are to productively utilize the available resources in local areas. The water resources available in the villages are often remain either unutilized or underutilized due to various reasons like lack technical knowledge on aquaculture, non-availability of quality seed, non-availability of quality inputs in time, lack of investment and support for inputs, marketing system, etc. In most of the villages, the available water resources are owned, controlled and managed by the village communities or self-help groups (SHGs) or panchayats, and the benefits used to be shared among the community members (Mohapatra and Barik, 2018). Aquaculture is taken as a part-time activity in most of the villages and sometimes a limited number of ponds fail to generate enough benefits to attract members to sustain their effort in aquaculture.

Hence, sustained efforts are to be undertaken to transfer many profitable aquaculture technologies like seed production and rearing practices, grow out fish culture, feed preparation, etc. to a large number of farmers (Mohapatra and Barik, 2018). The present study was focused on livelihood development of tribal communities in 58 villages under 17 Gram Panchayats of Koraput, Kotpad, Borigumma, Nandapur and Jeypore Blocks of Koraput District, Odisha and the technique of carp culture was demonstrated in ponds with 
minimum scientific interventions. The study was conducted under the Tribal Sub Plan (TSP) Scheme of Government of India operating at ICAR-CIFA during 2018-19. PRAGATI, Koraput was collaborator for the works undertaken in four Blocks i.e., Koraput, Kotpad, Borigumma and Nandapur and District Fisheries Office, Jeypore (Koraput) was for Jeypore Block. The tribal families of the adopted area were trained on various aspects of aquaculture for its adoption as an option for their livelihood development.

\section{Materials and Methods}

\section{Study area}

As per Government of India notification, Koraput is one of the Tribal Aspirational Districts of Odisha (https://my.msme.gov.in/MyMsme/List_of_Asp irationalDistricts.aspx). To demonstrate freshwater aquaculture technology as one of the livelihood options for tribal people, ICAR-CIFA adopted 58 villages under 17 Gram Panchayats of five Blocks i.e., Koraput, Kotpad, Borigumma, Nandapur and Jeypore of Koraput District, Odisha (Table 1). The Blocks adopted are shown in Fig. 1. The numbers of adopted families were 29, 70, 65, 7 and 50 from Koraput, Borigumma, Kotpad, Nandapur and Jeypore Blocks respectively. The villages are approximately $600-800 \mathrm{~km}$ away from Bhubaneswar, the capital city of Odisha. Surveys were conducted in different villages to find out the water sources and its possible use for fish farming. Assessment was done for introduction of scientific aquaculture practices following vivid discussions with the local people of the area involved directly or indirectly in aquaculture.

One hundred seventy six ponds with total water area of 22.168 ha (Table 1) were adopted from fifty eight villages for demonstration of aquaculture practices. The adopted ponds (total 6.2 ha) of Jeypore Block are perennial in nature and managed by Women Shelf Help Groups (WSHG). Those are Budhi Thakurani SHG at Telia (15 members), Mutyalamma SHG at Jamunda (15 members); Jayasanti SHG at Hordaput (10 members) and Bamandei SHG at Umuri (10 members). Remaining 171 ponds with water area 15.968 ha were adopted from Koraput, Kotpad, Borigumma and Nandapur Blocks. Out of those ponds eighty per cent are seasonal and water retains for 5-6 months for undertaking aquaculture activities.

The sizes of adopted ponds ranged between 0.01-2.0 ha with varying depths of 0.5-2.0 m. Before adoption, there were no scientific aquaculture operations in most of the selected ponds. The fish production was nil to 200 $\mathrm{kg} / \mathrm{ha} / \mathrm{yr}$. There was no sustainability in fish production from the ponds in different years. The small ponds dry on the onset of summer. The harvesting used to be done from all those ponds before drying to avoid fish loss due to poaching and mortality. During survey, it was calculated that the per capita fish contribution from aquaculture side to the food intake of the people was $0.01 \mathrm{~kg} /$ day.

\section{Pond preparation and input supply}

The ponds in different villages were prepared as per standard procedures followed for aquaculture. Before start of the culture operation, water samples from selected ponds of different blocks were collected for determining the pond health status. The ponds were applied with lime (@200 kg/ha) followed by fertilization by applying raw cow dung (@ 1000-1500 kg/ha) before stocking of carp seed (fingerlings). Monthly fertilization was continued by applying raw cow dung in the ponds. Several inputs like lime, nets, hapa, hundi, etc. were supplied from TSP-ICARCIFA. 


\section{IMC seed stocking and feeding}

Fingerlings of Indian major carps (Catla catla 65-85 mm \& 4.5-7.0 g, Labeo rohita 45-65 $\mathrm{mm} \& 3.5-5.5 \mathrm{~g}$ and Cirrhinus mrigala 42-60 $\mathrm{mm} \& 3.0-5.0 \mathrm{~g}$ ) were stocked with a density of 3,500/ha and ratio catla: rohu: mrigal: 1:2:1 in October-November, 2018. Due to nonavailability of sufficient fingerlings in the district, this low density of stocking was done to initiate the aquaculture demonstrations for the tribal farmers of the adopted areas.

Ground nut oil cake and rice bran with ratio $1:: 1$ and @ 2-5\% of their body weight was used as fish feed in first one month and then floating pellet feed was given to fishes @ $1.0 \%$ of their body weight. The feeds for fishes were supplied from TSP-ICAR-CIFA.

\section{Fish harvest}

The cultured fishes were harvested from the ponds of the adopted villages of Koraput, Kotpad, Borigumma and Nandapur Blocks in February-March, 2019 and of Jeypore Block in April-May 2019.

The length-weight and percentage of survival were recorded and production data for each pond was converted to the unit ' $\mathrm{kg} / \mathrm{ha} / \mathrm{yr}$ ' for comparison purposes,

\section{Physico-chemical parameters of pond water}

Physico-chemical parameters, i.e., water temperature $\left({ }^{0} \mathrm{C}\right), \mathrm{pH}$, dissolved oxygen $(\mathrm{mg} / \mathrm{l})$, total alkalinity $(\mathrm{mg} / \mathrm{l})$ and total hardness $(\mathrm{mg} / \mathrm{l})$ were analyzed from selected ponds of each block before start of the culture operation and during the practice. Those were estimated by following standard laboratory procedures (APHA-AWWA-WPCF, 1989).

\section{Awareness and trainings programmes conducted}

The TSP team from ICAR-CIFA had conducted five awareness and trainings programmes on scientific aquaculture activities to motivate the tribal families during demonstration operations in 2018-19 as follows:

Awareness programme and ScientistsFarmers Interaction Meet at Farmers' Field School, Dayanidhiguda, Koraput on 19 September, 2018 and 200 farmers and delegates from the district attended it.

Launching of TSP programme in Koraput District on 18 January 2019, in which more than 400 participants including farmers from five blocks, scientists, academicians, line department officials, press and media attended the event.

On 18 and 20 January, 2019 there were two training programmes on Freshwater aquaculture for tribal farmers in Jeypore and Dayanidhiguda of the district.

Awareness program on Carp seed production, nursery preparation and ornamental fish culture was conducted at Dayanidhiguda, Koraput on 7 June, 2019 for the farmers of Borigumma, Kotpad and Koraput.

Training-cum-demonstration of nursery preparation for fish spawn rearing was held during 28-29 June, 2019 in Koraput District. Fifty tribal farmers from adopted blocks attended it.

\section{Results and Discussion}

\section{Fish production achieved}

The demonstration of scientific IMC farming with low stocking density of 3,500 nos fingerlings/ha was conducted for 4-6 months amongst tribal farmers of 58 villages under 17 Gram Panchayats of Koraput, Kotpad, 
Borigumma, Nandapur and Jeypore Blocks of Koraput District, Odisha during OctoberNovember, 2018 to March-April, 2019. Out of this culture period, December and January months were in winter season, where the average water temperature went below $24^{0} \mathrm{C}$. Farmers intermittently harvested fish from their ponds for own consumption and for small marketing, but kept the harvest data recorded. It accounted 20-30\% of final harvest figure. Final harvesting was done during February-May, 2019. The total fish harvesting and survival data from different Gram Panchayats are presented in Table 2 and Fig. 2 and 3. Growth of the IMC in different Blocks is presented in Table 3. Fish production was better in Jeypore Block (1445 $\mathrm{kg} / \mathrm{ha} / \mathrm{yr}$ ) followed by Borigumma (1274.6 kg/ha/yr), Kotpad, (1061.9 kg/ha/yr), Koraput (827 kg/ha/yr) and Nandapur (771.4 $\mathrm{kg} / \mathrm{ha} / \mathrm{yr}$ ). Pooling all fish production data the average was calculated to be $1206.6 \mathrm{~kg} / \mathrm{ha} / \mathrm{yr}$. The survivability of fish during culture period ranged between 35-60 per cent.

In an area saturation mode, demonstration of freshwater aquaculture technology for livelihood development of tribal people of Niladriprasad Gram Panchayat, Banpur Block, Khordha District, Odisha was undertaken by ICAR-CIFA during 2015-2016 (Mohapatra et al., 2018a). Fish production was increased from the pre-adoption level of $250 \mathrm{~kg} / \mathrm{ha} / \mathrm{yr}$ to $428.5-2,880 \mathrm{~kg} / \mathrm{ha} / \mathrm{yr}$ in the twenty adopted villages of the block and average fish production was $1,372.6 \mathrm{~kg} / \mathrm{ha} / \mathrm{yr}$. In the present study the fish production in tribal farmers ponds of Koraput District was 771.4-1445 kg/ha/yr (average 1206.6 $\mathrm{kg} / \mathrm{ha} / \mathrm{yr}$ ) from a pre-adoption level of nil-200 $\mathrm{kg} / \mathrm{ha} / \mathrm{yr}$. More than $600 \%$ increase in fish production recorded from the adopted ponds. The results of both studies are more or less similar and the lower fish production in Koraput District can be linked to lower stocking density of fish and major culture period was in winter months. In DBT (Govt. of India) funded project, ICAR-CIFA could demonstrate $2,986 \mathrm{~kg} / \mathrm{ha} / \mathrm{yr} \quad(1,750-4,667$ $\mathrm{kg} / \mathrm{ha} / \mathrm{yr}$ ) in SC/ST farmers ponds in Nayagarh District and 2,433.5 kg/ha/yr (1,050-5,075 kg/ha/yr) in Mayurbhanj District, Odisha from the pre-adopted baseline value of 250 and $408 \mathrm{~kg} / \mathrm{ha} / \mathrm{yr}$ respectively (CIFA, 2012-13). Through participatory approach mode by mobilizing communities, stocking ponds and adopting all Scientific Management Practices in Khordha District, Odisha (Ananth et al., 2014) during 2011-13, they demonstrated the fish culture in five community ponds with water spread area (WSA) 6.0 ha. Average production of 2,241 $\mathrm{kg} / \mathrm{ha} / \mathrm{yr}$ was achieved against the farmer's practice level of $1,546 \mathrm{~kg} / \mathrm{ha} / \mathrm{yr}$. This value is higher than the present value, as the culture period was for less duration and continued through the winter months in Koraput District. In an area saturation model scientific demonstration of freshwater aquaculture technology was conducted in Jamushahi Cluster ponds of Daspalla Block, Nayagarh District, Odisha (Mohapatra et al., 2018b). Fourteen ponds totalling to WSA 4.6 ha from six villages, namely Jamusahi, Banibiri, Gundiribari, Durgaprasad, Pamporada and Tanganadi with 4,725 tribal population were adopted by ICAR-CIFA and ponds were stocked with the fingerlings of Indian major carps (IMC) i.e., Catla catla, Labeo rohita and Cirrihinus mrigala in October 2015. The stocking density was 5,000 nos/ha and species ratio was $1: 1: 1$. After a culture period of 7.5 months, the fish production was increased from pre-adoption level of $250 \mathrm{~kg} / \mathrm{ha} / \mathrm{yr}$ to an average of $1,157 \mathrm{~kg} / \mathrm{ha} / \mathrm{yr}$. Final fish harvest ranged between 666-3,049 kg/ha/yr in all 14 ponds of six adopted villages. The results of fish production from Jamushahi Cluster and Koraput District are in agreement to each other. Scientific aquaculture practices was demonstrated in four adopted villages, namely Ambapur (Digapahandi Block), Daseipur 
(Sanakhemundi Block), Nuapada (Kukudakhandi Block) and Sujanasahi (Khallikote Block) of Ganjam District, Odisha for fish production enhancement from ponds with livelihood and nutritional security of tribal farmers (186 families) of that area (Mohapatra et al., 2018c). Sixteen ponds with total water spread area of 11.6 ha were adopted by ICAR-CIFA through the DST (Government of India) sponsored project. Fingerlings of Indian major carps (IMC) were stocked at a density of 5,000/ha and ratio catla: rohu: mrigal: : 1:2:1 in October, 2017.
After 6-8 months of culture period, the growth of $C$. catla was $252-285 \mathrm{~mm} \& 600-$ $755 \mathrm{~g}$, L. rohita $215-260 \mathrm{~mm} \& 350-585 \mathrm{~g}$ and C. mrigala $195-250 \mathrm{~mm} \& 380-530 \mathrm{~g}$. Fish harvests were done during April-May, 2018 and productions ranged between 1.8-2.9 $\mathrm{t} / \mathrm{ha} / \mathrm{yr}$ from a pre-adoption production level of 0.6-1.1 t/ha/yr. The fish growth and ratio were more or less similar for Ganjam and Koraput demonstrations, but higher production in Ganjam can be attributed to higher stocking density of fish.

Table.1 Selected villages and water resources from Koraput District for demonstration of scientific aquaculture practices

\begin{tabular}{|c|c|c|c|c|}
\hline Block & Gram Panchayat & Village & No of Ponds & Area of Ponds (ha) \\
\hline \multirow[t]{4}{*}{ Nandapur } & Atanda & Atanda & 4 & 0.21 \\
\hline & \multirow[t]{3}{*}{ Badel } & Khamara & 2 & 0.08 \\
\hline & & Godiput & 1 & 0.09 \\
\hline & & Masuri & 1 & 0.04 \\
\hline \multicolumn{3}{|r|}{ Sub total } & 8 & $\mathbf{0 . 4 2}$ (Ave. 0.053 ) \\
\hline \multirow[t]{10}{*}{ Koraput } & \multirow[t]{8}{*}{ Mahadeiput } & Mahadeiput & 15 & 0.9425 \\
\hline & & Ekdeli & 2 & 0.08 \\
\hline & & Doliamb & 1 & 0.04 \\
\hline & & Karanjiguda & 3 & 0.12 \\
\hline & & Bilaput & 1 & 0.09 \\
\hline & & Badamput & 1 & 0.0625 \\
\hline & & Putpondi & 1 & 0.04 \\
\hline & & Jamadarguda & 2 & 0.4 \\
\hline & \multirow[t]{2}{*}{ Kendar } & Mastiguda & 2 & 0.08 \\
\hline & & Dayanidhiguda & 1 & 0.0225 \\
\hline & & Sub total & 29 & $\mathbf{1 . 8 8}$ (Ave. 0.06) \\
\hline \multirow[t]{4}{*}{ Jeypore } & \multirow[t]{2}{*}{ Telia } & Telia & 1 & 0.8 \\
\hline & & Jamunda & 2 & 2.8 \\
\hline & \multirow[t]{2}{*}{ Kumuliput } & Hordaput & 1 & 2.0 \\
\hline & & Umuri & 1 & 0.6 \\
\hline & & Sub total & 5 & 6.2 (Ave. 1.24) \\
\hline \multirow[t]{4}{*}{ Kotpad } & \multirow[t]{4}{*}{ Chitra } & Chitra & 6 & 1.4825 \\
\hline & & Kurmakote & 8 & 0.8225 \\
\hline & & P. Nayakguda & 2 & 0.0625 \\
\hline & & Jhaliaguda & 1 & 0.25 \\
\hline
\end{tabular}




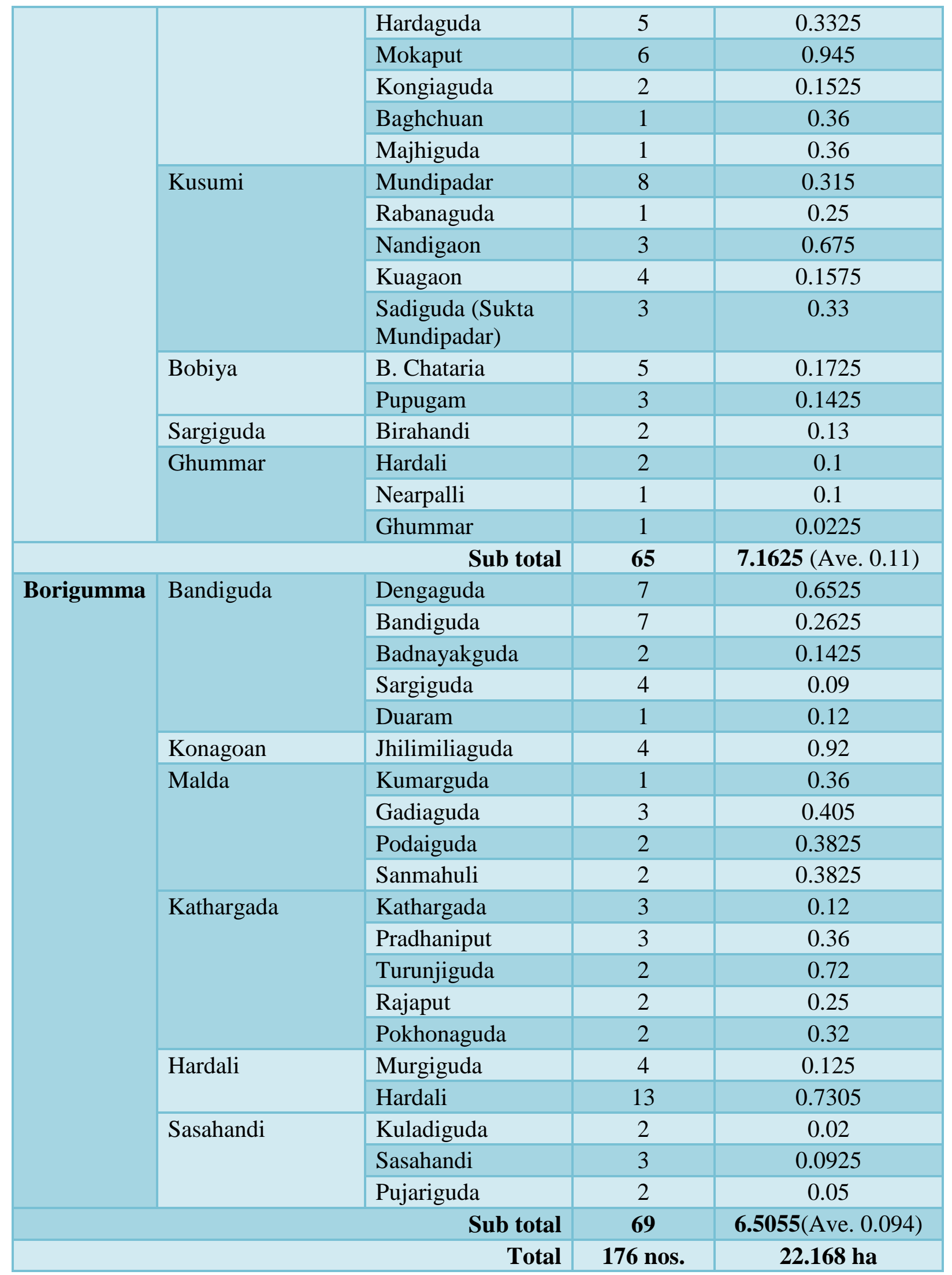


Table.2 Fish production from adopted ponds of Koraput District, Odisha

\begin{tabular}{|l|l|l|l|l|l|l|l|}
\hline Block & $\begin{array}{l}\text { Gram } \\
\text { Panchayat }\end{array}$ & $\begin{array}{l}\text { No of } \\
\text { Ponds }\end{array}$ & $\begin{array}{l}\text { Area of } \\
\text { Ponds (ha) }\end{array}$ & $\begin{array}{l}\text { Culture } \\
\text { Period } \\
\text { (Months) }\end{array}$ & $\begin{array}{l}\text { Fish } \\
\text { Production } \\
(\mathbf{k g})\end{array}$ & $\begin{array}{l}\text { Fish } \\
\text { Production } \\
(\mathbf{k g} / \mathbf{h a} / \mathbf{y r})\end{array}$ & $\begin{array}{l}\text { Survival } \\
(\mathbf{\%})\end{array}$ \\
\hline Nandapur & Atanda & 4 & 0.21 & 4 & 51 & 728.6 & $35-45$ \\
\hline & Badel & 4 & 0.21 & 4 & 57 & 814.3 & $40-50$ \\
\hline Koraput & Mahadeiput & 26 & 1.765 & 4 & 480 & 815.9 & $40-55$ \\
\hline & Kendar & 3 & 0.1225 & 4 & 38 & 1102 & $40-50$ \\
\hline & & & $\mathbf{1 . 8 8}$ & & $\mathbf{5 1 8}$ & $\mathbf{8 2 7}$ & $\mathbf{4 0 - 5 5}$ \\
\hline Jeypore & Telia & 3 & 3.6 & 6 & 2180 & 1211 & $50-55$ \\
\hline & Kumuliput & 2 & 2.6 & 6 & 2300 & 1769 & $50-60$ \\
\hline & & & $\mathbf{6 . 2}$ & & $\mathbf{4 4 8 0}$ & $\mathbf{1 4 4 5}$ & $\mathbf{5 0 - 6 0}$ \\
\hline Kotpad & Chitra & 32 & 4.7675 & 5 & 2200 & 1107.5 & $35-50$ \\
\hline & Kusumi & 19 & 1.7275 & 5 & 750 & 1042 & $35-55$ \\
\hline & Bobiya & 8 & 0.315 & 5 & 105 & 800 & $40-45$ \\
\hline & Sargiguda & 2 & 0.13 & 5 & 44 & 812 & $40-45$ \\
\hline & Ghummar & 4 & 0.2225 & 5 & 70 & 755 & $35-40$ \\
\hline & & & $\mathbf{7 . 1 6 2 5}$ & & $\mathbf{3 1 6 9}$ & $\mathbf{1 0 6 1 . 9}$ & $\mathbf{3 5 - 5 5}$ \\
\hline & Bandiguda & 21 & 1.2675 & 5 & 710 & 1344.4 & $40-60$ \\
\hline & Konagoan & 4 & 0.92 & 5 & 360 & 939 & $40-50$ \\
\hline & Malda & 8 & 1.53 & 5 & 815 & 1278.4 & $40-50$ \\
\hline & Kathargada & 12 & 1.77 & 5 & 980 & 1328.8 & $35-55$ \\
\hline & Hardali & 17 & 0.8555 & 5 & 520 & 1458.8 & $35-60$ \\
\hline & Sasahandi & 7 & 0.1625 & 5 & 70 & 1033,8 & $40-50$ \\
\hline & & & $\mathbf{6 . 5 0 5 5}$ & & $\mathbf{3 4 5 5}$ & $\mathbf{1 2 7 4 . 6}$ & $\mathbf{3 5 - 6 0}$ \\
\hline
\end{tabular}

Table.3 Growth estimation of fish in farmers' ponds in five blocks of Koraput District

\begin{tabular}{|c|c|c|c|}
\hline \multirow[t]{2}{*}{$\begin{array}{l}\text { Name of the } \\
\text { Blocks }\end{array}$} & \multirow[t]{2}{*}{$\begin{array}{l}\text { Species } \\
\text { cultured }\end{array}$} & \multicolumn{2}{|c|}{$\begin{array}{l}\text { Growth estimation during harves } \\
\text { (February-May 2019) }\end{array}$} \\
\hline & & Length (mm) & Weight (g) \\
\hline \multirow[t]{3}{*}{ Nandapur } & C. catla & $220-265$ & $410-600$ \\
\hline & L. rohita & $210-250$ & $375-450$ \\
\hline & C. mrigala & $205-225$ & $320-390$ \\
\hline \multirow[t]{3}{*}{ Koraput } & C. catla & $210-250$ & $450-530$ \\
\hline & L. rohita & $200-235$ & $340-420$ \\
\hline & C. mrigala & $195-225$ & $290-410$ \\
\hline \multirow[t]{3}{*}{ Jeypore } & C. catla & $275-320$ & $600-1150$ \\
\hline & L. rohita & $245-265$ & $550-750$ \\
\hline & C. mrigala & $220-280$ & $480-650$ \\
\hline \multirow[t]{3}{*}{ Kotpad } & C. catla & $280-300$ & $650-800$ \\
\hline & L. rohita & $215-275$ & $350-660$ \\
\hline & C. mrigala & $210-240$ & $400-580$ \\
\hline \multirow[t]{3}{*}{ Borigumma } & C. catla & $270-305$ & $635-900$ \\
\hline & L. rohita & $215-275$ & $350-700$ \\
\hline & C. mrigala & $200-250$ & $380-610$ \\
\hline
\end{tabular}


Fig.1 Adopted Blocks in Koraput District, Odisha for aquaculture demonstration

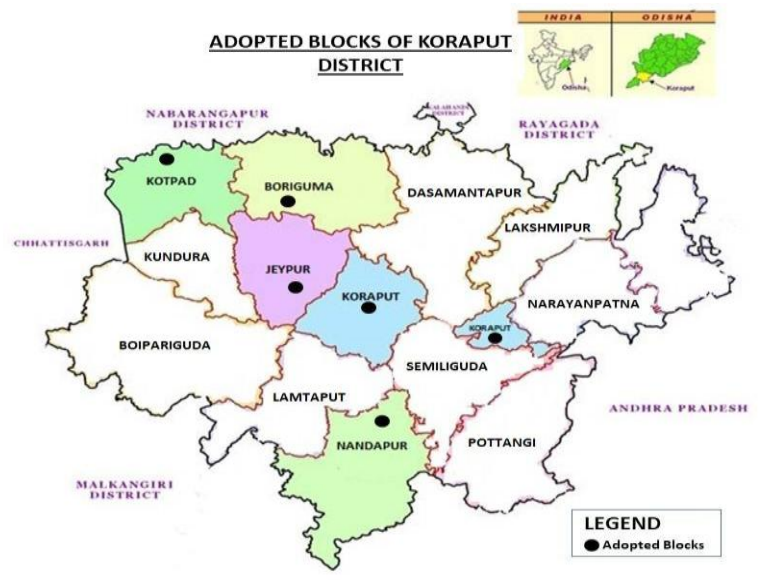

Fig.2 Gram Panchayat-wise adopted ponds and its area

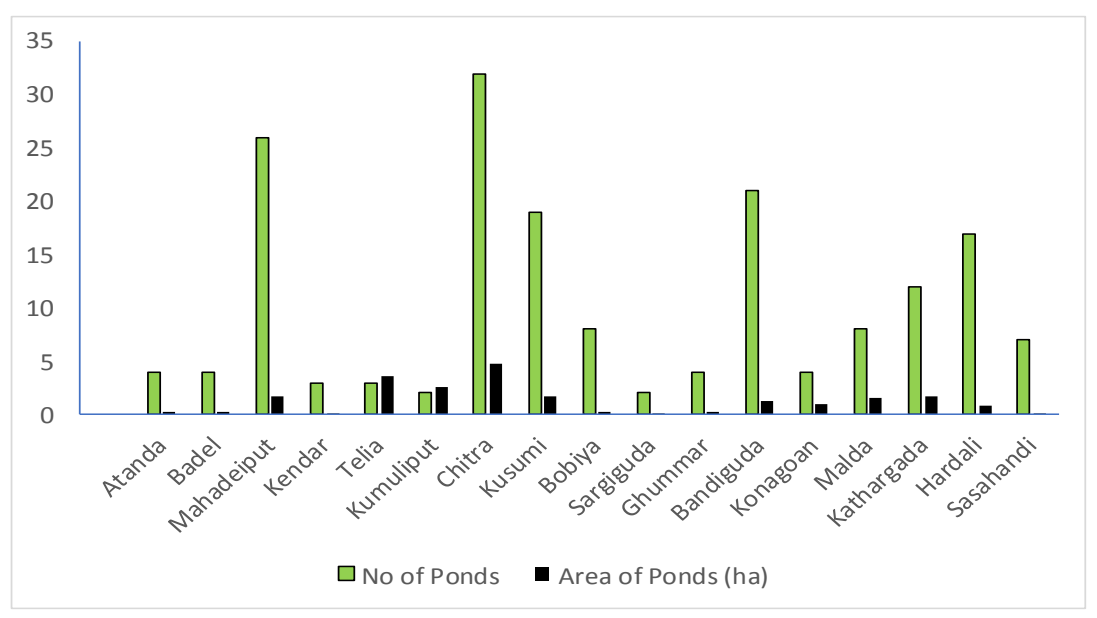

Fig.3 Fish production and survival in different adopted ponds of 17 Gram Panchayat

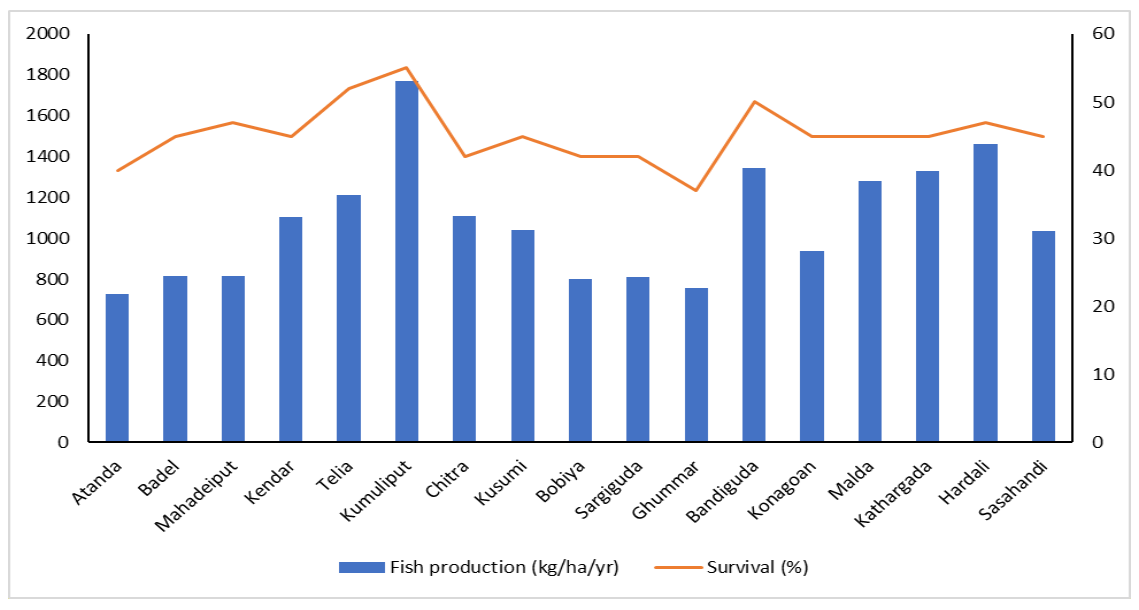




\section{Physico- chemical properties of pond water}

Physico-chemical parameters such as pond water temperature ranged between $21.0-34.5{ }^{\circ} \mathrm{C}$, pH 7.1-8.3, dissolved oxygen $2.5-5.5 \mathrm{mg} / \mathrm{l}$, total alkalinity $80-140 \mathrm{mg} / \mathrm{l}$ and total hardness 60 $120 \mathrm{mg} / \mathrm{l}$ in the selected ponds of Koraput District. The sampling data revealed that the water parameters of all adopted ponds were suitable for aquaculture purpose (Mohapatra and Saha, 2000). The water quality requirement for carp culture in ponds is more than $3.0 \mathrm{mg} / \mathrm{l}$ for dissolved oxygen, $100-200 \mathrm{mg} / \mathrm{l}$ total alkalinity, $20-30 \mathrm{~cm}$ transparency and more than $40 \mathrm{mg} / 1$ total hardness (Mohapatra et al., 2013).

\section{Livelihood development}

Continuous direct interactions with tribal people regarding their need, motivation to the whole community (including youth and women) for aquaculture, regular visits to them during interventions, supply of inputs, demonstration of different technologies and trainings on related aspects of aquaculture enabled them to take aquaculture in a scientific manner. Preliminary survey revealed that the farmers are engaged in different types of agricultural practices and aquaculture comes as secondary or tertiary option for them. It is due to ignorance to scientific farming practices and poaching of fish.

As the variable costs and revenues increase with the size of pond, smaller ponds can generate a good crop of fish with a lower investment cost (Guha et al., 2006). It is identified from the people-centered approaches that the seasonal ponds are especially attractive for farmers who are poor and first time aquaculturists. The utilization of these ponds not only increases their economic condition, but also supports their nutritional security in respect of availability of animal protein to them. Similar results were seen from the areas that were adopted in the present study. 20-30 per cent of fish produce has gone to their kitchen and rest for economy. The per capita fish contribution from aquaculture to the adopted beneficiaries was calculated to be $0.025 \mathrm{~kg} /$ day. It is reported that the fish farming has improved the socioeconomic condition and food security of people in the villages of Duruguda and Gopalputar near Koraput-Sunabeda NH-26 in Koraput District (https://www.orissapost.com/fish-farmingspawns-income-in-koraput-villages/).

The livelihood of the tribal people can further be increased by increasing the fish production from their ponds by adopting higher level of technologies, increasing fish stocking density, bringing high valued fishes to the culture system, increasing access to inputs and, marketing and intensive training programmes.

\section{Acknowledgement}

The authors sincerely acknowledge the financial support from the Tribal Sub Plan Programme of Government of India operating at ICAR-Central Institute of Freshwater Aquaculture, Bhubaneswar, Odisha, India and the Director, ICAR-CIFA for providing facilities for the study.

\section{References}

Ananth P.N., P.R. Sahoo, A.K. Dash, B.K. Pati, P. Jayasankar and S.R.K. Singh, 2014. A study on community based aquaculture promoted by KVK-Khordha, Odisha, India. Current World Environment, 9(3): 947-951.

APHA-AWWA-WPCF, 1989. Standard methods for the examination of water and wastewater. American Public Health Association, New York: 1-1193.

CIFA, 2012-13. Annual Report. ICAR-Central Institute of Freshwater Aquaculture, Bhubaneswar, Odisha: 1-165.

FAO, 2010. The state of food insecurity in the world, addressing food insecurity in protracted crises. Food \& Agriculture Organization, Rome, 19.

Government of Odisha (GoO), 2017-18. Annual Activity Report, 2017-18. Fisheries and Animal Resources Development 
Department, Government of Odisha: 150.

Guha R.G., K.S. Haylor, P. Khandagiri, S.K. Mahapatra, R. Mukherjee, A. Patel, K. Paul, S.N. Singh and S.D. Tripathi, 2006. Joint Review Mission Report On Aquaculture Development. Orissa Watershed Development Mission/ NR International/ STREAM Initiative / WORLP: $1-50$.

Mohapatra B.C. and C. Saha, 2000. Aquatic pollution and management. Central Institute of Freshwater Aquaculture, Bhubaneswar: 1-363.

Mohapatra B.C., B.K. Das, K.N. Mahanta, P.P Chakrabarti, N.K. Barik and P. Jayasankar, 2013. Carp culture in freshwater ponds. ICAR-Central Institute of Freshwater Aquaculture, Bhubaneswar. Pp. 1-36.

Mohapatra B.C. and N.K. Barik, 2018. Development of model village cluster for aquaculture: A case in Begunia Block of Khordha District, Odisha, India. International Journal of Fisheries and Aquatic Studies, 6(2): 534-540.

Mohapatra B.C., N.K. Barik, U.K. Udit et al., 2018a. Area saturation model of freshwater aquaculture technology demonstration for livelihood development of tribal farmers of Niladriprasad Gram Panchayat of Banpur Block, Khordha District, Odisha. Journal of Natural Resources \& Development. 13(1): 18-26.

Mohapatra B.C., U.L. Mohanty, D.P. Rath, H. Sahu, S.K. Mahanta and D. Majhi, 2018b. Freshwater aquaculture technology demonstration in area saturation mode to the tribal farmers of Jamushahi Cluster of Daspalla Block,
Nayagarh District, Odisha. International Journal of Fisheries and Aquatic Studies. 6(4): 319-324.

Mohapatra B.C., N.K. Maharana, A.D. Sahu, S.K. Jena, M. Mahapatra and S.P. Bhoi, 2018c. Scientific freshwater fish culture demonstration in some tribal villages of Ganjam District, Odisha. International Journal of Fisheries and Aquatic Studies, 6(5): 336-341.

Mondal M.A.H., M.M. Ali, P.K. Sarma and M.K. Alam, 2012. Assessment of aquaculture as a means of sustainable livelihood development in Fulpur upazila under Mymensingh district. Journal of Bangladesh Agriculture University, 10(2): 391-402.

NFDB, 2017. Physical progress under blue revolution scheme (2015-17). World Fisheries Day Souvenir, Ministry of Agriculture and Farmers Welfare, DAHDF, Government of India, New Delhi.

Rajee O. and A.T.K. Mun, 2017. Impact of aquaculture on the livelihoods and food security of rural communities. International Journal of Fisheries and Aquatic Studies, 5(2): 278-283.

Shrestha M.K. and J. Pant, 2012. Small-scale aquaculture for rural livelihoods: Symposium Proceedings on 'Smallscale aquaculture for increasing resilience of rural livelihoods in Nepal', 5-6 February 2009, Kathmandu, Nepal, (C) The WorldFish Center, Penang, Malaysia: 1-189.

The Pioneer, 2017. Odisha people eat fish more, eggs less. The Pioneer, Bhubaneswar, 2 March, 2017.

\section{How to cite this article:}

Mohapatra, B. C., Prabhati K. Sahoo, K. D. Mahapatra, A. Barat, P. K. Sahoo, G. M. Siddaiah, D. Panda, U. L. Mohanty, D. K. Verma, D. Majhi, J. K. Swain, P. Adhikari, L. Panda, B. Ratha and Pillai, B. R. 2020. Aquaculture as a Component for Livelihood Development of Tribal Farmers of Selected Blocks of Koraput District, Odisha, India. Int.J.Curr.Microbiol.App.Sci. 9(09): 188-198. doi: https://doi.org/10.20546/ijcmas.2020.909.024 